\title{
From one extreme to another- treatment challenges and dilemmas in a transdiagnostic day program
}

\author{
Judith Leahy ${ }^{1 *}$, Melanie Clark ${ }^{1}$, Cate Borland ${ }^{1}$, Ursula Scott ${ }^{1}$, Rosemary Blundo ${ }^{2}$, Teresa Davids ${ }^{2}$ \\ From 2013 ANZAED Conference: Inspiring Change: Person and Context \\ Melbourne, Australia. 23-24 August 2013
}

Can you treat someone with a BMI 15 alongside someone with a BM 48 ? Will there be more differences than similarities? These were some questions faced when deciding inclusion criteria in our transdiagnositic Central Coast Day Program.

We use Acceptance and Commitment Therapy (ACT) in treatment. The use of a 'values based' approach is helpful in recovery providing 'common ground' for clients who are in the same 'eating disorder boat'.

One aim of treatment is to not restrict or reduce intake of any type of food but rather restore 'freedom around food'.

We use a 'self-observation log', a valuable tool to monitor and analyse emerging patterns between daily food intake, eating behaviours and psychological Room: State.

Our Challenges and dilemmas are:

How do we retain someone with Anorexia Nervosa when cognitively ready for recovery but not 'behaviourally' ready; a Day Program helps contain behaviours but $69 \%$ of binges occur in the evening; a client with BED gains an additional $14 \%$ body weight in 8 months of treatment; what do you do when someone no longer meets BED criteria but is still overeating and, is it 'better' to just be morbidly obese rather than be morbidly obese and have an eating disorder?

This abstract was presented in the Adult Treatment and Services stream of the 2013 ANZAED Conference.

\section{Authors' details}

${ }^{1}$ Central Coast Local Health District, NSW Ministry of Health, Australia. ${ }^{2}$ Arts for Health, Australia.

\footnotetext{
*Correspondence: jleahy@nsccahs.health.nsw.gov.au

${ }^{1}$ Central Coast Local Health District, NSW Ministry of Health, Australia

Full list of author information is available at the end of the article
}

Published: 14 November 2013

doi:10.1186/2050-2974-1-S1-04

Cite this article as: Leahy et al:: From one extreme to another-

treatment challenges and dilemmas in a transdiagnostic day program.

Journal of Eating Disorders 2013 1(Suppl 1):04.
Submit your next manuscript to BioMed Central and take full advantage of:

- Convenient online submission

- Thorough peer review

- No space constraints or color figure charges

- Immediate publication on acceptance

- Inclusion in PubMed, CAS, Scopus and Google Scholar

- Research which is freely available for redistribution

\section{() Biomed Central}

